ISSN 2073-4441

www.mdpi.com/journal/water

Article

\title{
Economic Effects of Legislative Framework Changes in Groundwater Use Rights for Irrigation
}

\author{
Giacomo Giannoccaro $^{1, *}$, Maurizio Prosperi ${ }^{2}$ and Giacomo Zanni ${ }^{3}$ \\ 1 Department of Agricultural Economics, Sociology and Policy, University of Cordoba, Campus de \\ Rabanales, Edificio C5, 14014, Cordoba, Spain \\ 2 Department of Production and Innovation in Mediterranean Agriculture and Food System (PrIME), \\ University of Foggia, Via Napoli 25, 71122 Foggia, Italy; E-Mail: m.prosperi@unifg.it \\ 3 Department of Engineering (EnDIF), University of Ferrara, Via Saragat 1, 44122 Ferrara, Italy; \\ E-Mail: giacomo.zanni@unife.it
}

* Author to whom correspondence should be addressed: E-Mail: es2gigig@uco.es; Tel.: +34-957-218-462; Fax: +34-957-218-539.

Received: 23 May 2011; in revised form: 23 August 2011 / Accepted: 30 August 2011 /

Published: 19 September 2011

\begin{abstract}
In most countries, groundwater resource is a public good, and the entitlement of use rights by the public authority to final users differs according to a country-specific legislative framework. In Italy, groundwater extraction has been regulated through non-tradable private licenses. At present, the public authority needs to reform the current legislative framework, in order to comply with the Water Framework Directive, aimed at the enhancement of the efficiency of the resource use. This research analyzes the effects of reforming the current framework based on non-tradable use rights, by comparing two different liberalization scenarios: an intra-sector market, and a regional market. Although positive economic benefits are generally expected from the liberalization of use rights at aggregated level, we want to analyze whether effects of the legislative framework causes uneven changes on some farm groups. The empirical case study refers to the Fortore river basin (South of Italy), where groundwater covers about $50-80 \%$ of current needs, and informal (though illegal) water markets across neighbor farmers already exist. From the findings, there is no evidence that the exchange liberalization of groundwater use rights leads to gains in terms of the value added and the farmer's revenue. In addition, in the case of an auction system regulated by the public authority, farmers whose water productivity is
\end{abstract}


higher may be able to gain, while others may suffer some losses. In this case, resistances from farmers' associations towards the legislative framework reform may arise.

Keywords: water markets; groundwater; Water Framework Directive; economic assessment

\section{Introduction}

Groundwater is a strategic resource for satisfying current water needs. According to some estimates across the world, groundwater is the major source of potable water in industrialized countries, such as in Europe (75\%) or in the US (51\%). In addition, it is also very important in other continents, such as Asia-Pacific (32\%), Latin America (29\%), and Australia (15\%) [1]. At the European level, the share of groundwater to water supply largely varies across countries, such as $100 \%$ in Denmark, $23 \%$ in Italy, and $13 \%$ in Germany and France [2].

Urban demographic growth and the consequent dramatic lifestyle change are behind the most important increases in water demand, most of which is supplied through the exploitation of the groundwater sources. For instance, the share of groundwater to potable water in Taiwan has risen from 21 to 40 percent, in only eight years (from 1983 to 1991) [1]. In addition, the exploitation of groundwater for irrigation purposes is also massive, and the growing demand for food will cause an increase in demand for water resources. Since it is likely that these trends of water demand will be confirmed, a further pressure on groundwater exploitation is also expected and, therefore, a risk of depletion for this resource is highly relevant [3].

In the past, some important legislative measures have been enacted, such as Directives 76/160/EEC (Quality of bathing water), 76/464/EEC (Water pollution by discharges of certain dangerous substances), 80/68/CEE (Groundwater protection against dangerous substances), 91/676/EEC (Nitrates Directive), 91/271/EEC (Urban Waste Water Treatment). However, the European Water Framework Directive (WFD) $2000 / 60 / \mathrm{CE}$ is innovative in the sense that it promotes an integrated and holistic water management approach, targeting all water bodies and pursuing a sustainable use of water resources, either from a quantitative or a qualitative perspective.

Nonetheless, the fact that the directive puts a strong emphasis on the concept of economic efficiency as in the case of a generic commodity, has alerted the public concern, since it has been interpreted as an attempt to transform a public good into a private commodity, that can be sold, purchased and subject to economic speculators. This vision neglects the multidimensional role of the water resource, which is not only devoted to productive purposes, but is also an indispensable good to human needs and to ecological systems [4].

At present, there is general difficulty in controlling groundwater extraction for agricultural purposes. For instance, in Italy, as in other EU countries, the historical development of water rights can be summarized as a progressive establishment of public power over a free-access common property. The key characteristics of the Italian water institutions can be summarized as follows [5]: (i) sectoriality (water legislation evolved to respond to specific water uses): (ii) fragmentation (competences in the water domain are exerted by a large number of different administrations and 
territorial levels); (iii) emergency driven (advances in the regulatory settings occur when emergencies exert pressure on the policymaker); (iv) dominated by supply-side and public-work approaches.

Consequently, groundwater extraction is basically regulated through non-marketable private licenses without clear access rules, nor a specific quantity constraint. Although the drill of private wells is subject to public authorization or licensing, in many cases the public authority is incapable of (or unwilling to) prohibit illegal or excessive water abstraction. However, under the new legislative course promoted by the WFD, the authorities have to enact several measures to achieve the quantitative and qualitative goals by 2015. In that sense, the restrictions to water access and extraction are likely to be introduced or strengthened in most of European countries [6].

At present, the use rights cannot be traded therefore farmers with historical rights will take an advantage position for a likely restriction of groundwater use rights. Additionally, a further cause of inefficient use relies on the fact that in some countries (e.g., Italy) the exchange of water use rights among farmers is not allowed. In this context, this research analyzes economic effects of reforming the current framework of use rights for irrigation purpose. In order to investigate on the mentioned aspects, in this study a reform of the current framework based on non-tradable use rights is proposed. In this regard, two alternative liberalization settings are assumed, by which the groundwater exchange is opened and the access rights are re-addressed. With the first hypothesis, farmers are enabled to exchange their historical water use rights. Therefore farmers capable of the most (economic) profitable use will be interested in the purchase of the resource from other farmers, who will find the opportunity to sell their rights, within the entitlements currently assigned by the public authority.

With the second scenario, it is assumed that the public authority may recall the current use rights, and re-distribute them to farmers, through an auction system. Therefore a re-allocation of use rights is expected, where the most profitable farms capable of purchasing as much use rights as they need, directly from the public authority, at a given price depending on their willingness to pay.

The motivation of this study is that, although positive economic benefits are generally expected from the liberalization process at aggregated level, we want to evaluate whether a win-win effect is occurring in all types of farms, or if some differences may emerge. The empirical case-study refers to the Fortore river basin, located in the South of Italy, where groundwater is currently over-extracted and covers about $50-80 \%$ of the current needs, as well as informal (though illegal) water markets across neighbor farmers which are already quite common.

The structure of the paper is the following. The next section reports a short review on groundwater concerns. Section 3 reports about the methodology and the data necessary for policy analysis. Results are illustrated in Section 4, while same concluding remarks are discussed in the last section.

\section{Key Issues in Groundwater Management}

The fraction of groundwater normally used for irrigation of field crops, mostly derives from water flowing through shallow aquifers, and can be considered a renewable natural resource. In several countries (e.g., Italy) it is conceived as a public good, which implies the emergence of market failures. In order to face the inefficient allocation of water use rights, property rights are often owned by the public authority, while the use rights may be entitled to private subjects, through temporary authorization or license, for specific private purposes (e.g., irrigation), except commercial uses. In this 
way, the public authority may exert a direct role on the protection of the resource stock and quality, through juridical tools based on the setting of the number of authorized wells and the definition of quality standards. While it is evident that this approach is based on the central role of the public authority, with the enactment of the WFD, the European Union attempts to introduce economic tools (e.g., pricing methods, tradable rights) to transfer the full cost of the water service (including the operational cost, resource cost, and externalities) directly to the final user and, therefore, to allocate water rights to the most (economic) efficient users. In this way an improvement of water use efficiency is expected.

An extreme attempt to favor an optimal allocation of the resource is through the establishment of markets of use rights. In the last decades, several countries have reformed their legislative framework to activate some sort of water market. In Chile, Australia and the United States, water markets have already been activated for several years [7], while in some other countries the process of reform started, but has not been completed yet, such as in the case of Canada [8], Spain [9,10], and South Africa [11].

However, in spite of the growing interest of economists and water management experts towards the potential gains achievable from the correct setting of use rights in the water markets, some empirical evidence emerges, supporting the fact that there are some risks which should be considered. For instance, according to the experience accumulated in Chile during the 15 years since the establishment of the market of both temporary and permanent use rights, there is evidence emerging from some research that the exchange intensity appears rather different across regions, due to: $(i)$ geographic characteristics and types of existing infrastructures; (ii) legal and administrative aspects; (iii) cultural factors and psychological attitude of local communities; (iv) prices and water value [12]. In the case of Australia, the intensity of the exchange seems affected by the water availability, the prices of the substitute products of agricultural commodities, and the fluctuation of prices of irrigated crops [13].

The creation of a market of groundwater use rights is subject to some prerequisite, necessary to ensure that demand and supply occur within a juridical context where the rights of both parties are guaranteed, such as the open access to full information to all possible participants, and the ability of the potential participants to participate in the negotiation and the transaction, at accessible cost [12]. However, empirical evidence has proved that transaction costs are relevant and may hinder the participation of small suppliers and users [14,15]. Some authors consider the exchange of permanent use rights, where the water resource may be fully considered as a sort of asset and could be sold independently from the farmland and, therefore, it is claimed that a reliable and updated informative source provided by the public institutions is needed, in order to protect the owner of use rights, similar to the case of the protection of property rights on farmland [12].

The change in the legislative framework to allow for the exchange of use rights may be possible and also necessary, but this process of reform should be based on the active involvement and participation of all stakeholders at community level. Worldwide, several countries have enforced a legislative framework to allow water markets. Among the most significant experiences, it is worth mentioning the Cile's 1981 water law, where existing water users were granted of property rights without charge. However, the state auctions new property rights which, under certain regulations, can be sold to anyone, for any purpose, at free negotiated prices [16]. 
Another example is Peru's 1993 constitution, where land and water resources are treated equivalently, and thus permits tradable property rights to water. In addition, a draft water law proposes that these rights can be traded, leased, or used as collateral. Property rights holders are enabled to get property rights free of charge, either implicitly by custom or explicitly through licenses and permits. On the contrary, rights for unused water would be auctioned subject to some protections, such as: (i) ensuring that the availability of water to others is not reduced; (ii) that there is enough water to maintain a minimum ecological flow; and (iii) that people in neighboring towns retain their accustomed access [17].

In recent years, several states in Australia have established property rights to water, though they have initially placed substantial restrictions on intersectoral trading [13].

With regard to Europe, in France the reform allowing the exchange of temporary water user rights has recently been promoted, with a strong emphasis on the principles of transparency, democracy, and solidarity, which reflect the consolidated cultural background of this country. On the contrary, typical economic principles, here are less important, but having more importance in countries characterized by the anglo-saxon culture [18].

\section{Simulation of the Legislative Framework Change Referred to the Case Study of the Fortore River Basin}

The empirical exercise described below attempts to get a broad understanding of the magnitude of economic gains and losses consequent to the reform of the legislative framework on groundwater use rights. The exercise consists of comparing the situation before and after the reform. However it is worth mentioning that in order to complete an eventual reform on such a sensitive matter, a long process of politic discussion and public involvement is necessary, and may also induce legal actions of some affected parties against the State. All these aspects obviously will imply some highly relevant costs, in terms of time for discussion and voting, as well as private and public costs to cover legal fees and trial costs.

In addition, this analysis is focused only on the current effects on irrigated agriculture, given that in the South of Italy, similar to other arid and semi-arid regions, irrigation is the economic activity exerting the highest pressure on groundwater sources. Although irrigated agriculture is undoubtedly profitable and also plays a strategic role for industrial food chains (e.g., processed tomato, wine, olive oil), the need for a sustainable approach is acknowledged, since groundwater extraction affects the profitability of neighbor users, the depletion of the resource, and the endowments for future generations.

\subsection{Data Collection}

Technical data. The case study refers to a flat area served by irrigation infrastructures of pipelines conveying pressured water, managed by the local irrigation board called 'Consorzio per la Bonifica della Capitanata' (CBC) (see Figure 1). The irrigation project was completed in the 1960s and converted traditional rain fed agriculture based on pastures and winter cereals, in more intensive agriculture, that was also stimulating the demand for additional water sources. Indeed private wells have been largely drilled without strict control from the public authority. Their distribution has been 
also affected by the water accessibility to the $\mathrm{CBC}$, which still represents the most convenient and low-cost water source. For this reason, groundwater is often a complementary source either to enlarge the irrigated area, and also to guarantee the availability of irrigation in case of water shortage from the CBC, which depends on the rainfall patterns in the autumn and winter [19]. The percentage of water from $\mathrm{CBC}$ and groundwater from private wells annually varies according to the $\mathrm{CBC}$ availability. Usually the share amounts to $50 \%$ between the two sources, but during exceptionally long drought periods the groundwater can reach $100 \%$ of irrigation water [19].

Figure 1. The study area (Apulia region, Foggia province). The faded area is served by the CBC.

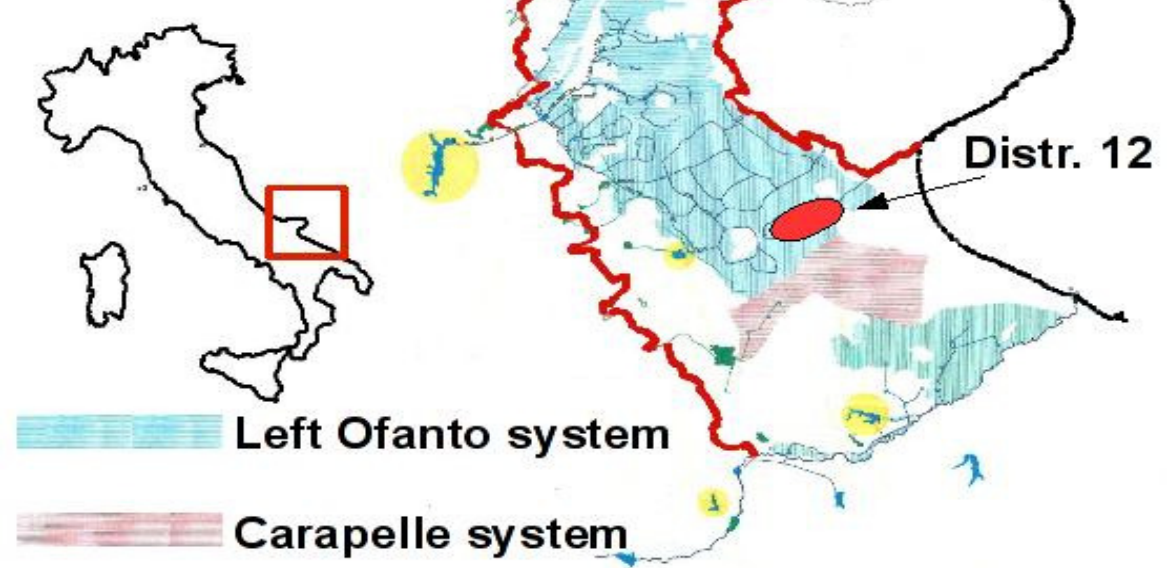

Although the overall irrigation infrastructure covers about 135,000 ha, the economic analysis refers to a representative area (the District 12) of 11,300 ha, devoted to wheat, tomato for the processing industry, and some other horticulture crops (e.g., asparagus, artichoke, cabbage). The yearly amount of water conveyed by the $\mathrm{CBC}$ amounts to 10 million cubic meters, and an equivalent amount is estimated to be extracted from private wells.

The farming structure consists of 1,198 farms, with the average size ranging from 10 to 43 ha. According to a previous study conducted on the same area, five farm typologies can be shaped by means of a cluster analysis: ( $i$ ) small and part-time family farms; (ii) medium size farms with cereals and intensive horticultural crops; (iii) large size farms with cereals and intensive horticultural crops; (iv) average size farms with cereals, intensive horticultural crops and orchards; and (v) large size corporation farm. They mostly differ in terms of crop rotations, intensity of land renting and monthly hired and family work load (more details are available in [20]).

In order to simplify the empirical exercise, we selected only the two main types of farms, representing $82 \%$ of the operating farms, and $72 \%$ of the cultivated land.

As reported in Table 1, the first type is the common irrigated farm, where irrigated crops play a relevant role (tomato and other horticultural crops covering respectively $19 \%$ and $21 \%$ of the farmland). The second type is relatively less intensive, with larger farmland size, and relatively more simplified cropping patterns based on rain fed cereals and irrigated tomato. 
Table 1. Descriptive data of the two farm types.

\begin{tabular}{lcc}
\hline & Type 1 (intensive) & Type 2 (less intensive) \\
\hline Total farmland (ha) & 1,686 & 8,218 \\
Operating farms (number) & 180 & 805 \\
Farm size (ha) & 22 & 43 \\
Share of irrigated land (\%) & 45 & 28 \\
Specific water consumption ( $\left.{ }^{3} / \mathrm{ha}\right)$ & 1,672 & 2,579 \\
Cropping patterns: & & \\
$\quad$ winter cereals (mainly durum wheat) $(\%)$ & 50 & 70,00 \\
$\quad$ tomato for processing industry (\%) & 19 & 18 \\
$\quad$ horticultural crops (\%) & 21 & 7 \\
$\quad$ orchards (olive and vineyard) (\%) & 10 & 5 \\
\hline
\end{tabular}

Source: [20] from original data provided by CBC (Data referred to year 2003).

Defining the current situation of use rights (status-quo). At present, there are two main water irrigation sources: water conveyed by the $\mathrm{CBC}$ and groundwater from private wells.

Although the $\mathrm{CBC}$ is a private consortium of landowners, it is empowered by the public authority (the Apulia Region) to manage the water from the reservoir called 'Occhito', located in the mountainous area of the province of Foggia. Landowners have received water use rights by a system coupled with their own land, for an overall amount of water rights which is proportional to the land served by the infrastructure. The use rights are strictly linked with the land and depend on the presence of infrastructures, and cannot be sold separately (neither temporarily, nor permanently). The available amount of water supply varies according to the reservoir capacity, which depends on the rainfall during the previous year. Consequently, larger landowners take a revenue advantage, which becomes evident in terms of higher yields of irrigated crops, or higher market values.

The CBC adopts volumetric increasing block tariffs, and therefore farmers pay accordingly with their actual consumption. In more detail, during the year 2007, a three-tiered pricing has been applied, with a first block of $2,050 \mathrm{~m}^{3} / \mathrm{ha}$ at a lower tariff $\left(0.09 \mathrm{EUR} / \mathrm{m}^{3}\right)$, sufficient to cover their running costs, a second block of $950 \mathrm{~m}^{3} / \mathrm{ha}$, available at an intermediate tariff $\left(0.12 \mathrm{EUR} / \mathrm{m}^{3}\right)$, and the exceeding amount at a higher tariff $\left(0.24 \mathrm{EUR} / \mathrm{m}^{3}\right)$. This last tariff currently exceeds the water productivity of most farms, which is evaluated in terms of $0.18 \mathrm{EUR} / \mathrm{m}^{3}[20,21]$.

In the case of the management of groundwater, the responsibility is upon the public authority, which is empowered to release extraction licenses to legitimated farmers (upon agreement with the landowner) for agricultural purposes and for a limited temporal horizon (30 years). However, the difficulties of performing an accurate monitoring over a relatively wide, scarcely populated area, has also favored the spreading of a high number of illegal drills. Today about 45,000 wells are estimated over the overall CBC served area [22]. Furthermore, the public authority has collected data depicting a critical status of quality worsening, mostly due to the salinization process caused by the overexploitation that have induced the infiltration of sea water [23]. The Apulia Region has enacted the 
Regional Law n.9, of 21 May 2008, which introduces some changes in the procedure to get a groundwater right. Indeed, farmers are required to install measurement devices to record the amount extracted, as well as the periodical monitoring of the quality status, in terms of pollutants (e.g., nitrates and organic carbon) and salinization indicators. In order to exert an effective control on the volume extracted, a fixed allotment for each well has been determined. Furthermore, farmers are obliged to transmit data records to the public authority, and in the case of omission the authorization may be recalled. Finally, new permits (i.e., access) are banned, until a complete monitoring of the current situation will be achieved. In this sense from an economic perspective, an advantage rent position arises in favor of farmers benefiting from the current authorization regime.

According to the current state of the average water consumption for the two farm types in the study area, Table 2 reports the water availability either from the $\mathrm{CBC}$ and groundwater sources.

\subsection{Specification of Alternative Use Right Settings}

In order to proceed with the scenario formulation, three key factors that emerged from the literature analysis have been considered: ( $i$ ) type of user allowed for participating in the market; (ii) resource access type; and (iii) possibility to sell (or re-sell) the use rights.

Table 2. Current situation of groundwater use rights in the study area.

\begin{tabular}{|c|c|c|c|c|c|c|}
\hline \multirow{2}{*}{$\begin{array}{l}\text { Water } \\
\text { source }\end{array}$} & \multicolumn{3}{|c|}{ Farm Type 1 (intensive) } & \multicolumn{3}{|c|}{ Farm Type 2 (less intensive) } \\
\hline & Access & $\begin{array}{l}\text { Extraction } \\
\text { (year 2007) }\end{array}$ & Sale & Access & $\begin{array}{l}\text { Extraction } \\
\text { (year 2007) }\end{array}$ & Sale \\
\hline $\mathrm{CBC}$ & $\begin{array}{l}\text { Proportional to } \\
\text { the served land }\end{array}$ & $4,800 \mathrm{~m}^{3}$ & Forbidden & $\begin{array}{l}\text { Proportional to } \\
\text { the served land }\end{array}$ & $8,000 \mathrm{~m}^{3}$ & Forbidden \\
\hline Groundwater & $\begin{array}{l}\text { Historical record } \\
\text { of extraction; } \\
\text { banning of new } \\
\text { authorizations }\end{array}$ & $5,000 \mathrm{~m}^{3}$ & Forbidden & $\begin{array}{l}\text { Historical record } \\
\text { of extraction; } \\
\text { banning of new } \\
\text { authorizations }\end{array}$ & $7,500 \mathrm{~m}^{3}$ & Forbidden \\
\hline
\end{tabular}

Source: Adapted from [20].

Table 3. Features of use rights scenarios.

\begin{tabular}{llll}
\hline & Access right & Extraction right & Exchange right \\
\hline Status-quo & $\begin{array}{l}\text { Maintenance of the current } \\
\text { authorized wells. Block of new } \\
\text { authorizations }\end{array}$ & $\begin{array}{l}\text { Volumetric allotment corresponding } \\
\text { to historical records for each farm- } \\
\text { type }\end{array}$ & Forbidden \\
\hline $\begin{array}{l}\text { Intra-sector } \\
\text { market (A) }\end{array}$ & As status-quo & As status-quo & $\begin{array}{l}\text { Temporary use right } \\
\text { exchange allowed only } \\
\text { among farmers }\end{array}$ \\
\hline $\begin{array}{l}\text { Regional } \\
\text { market (B) }\end{array}$ & $\begin{array}{l}\text { Free access to groundwater } \\
\text { also to non-farmers, but } \\
\text { subject to payment of } \\
\text { volumetric tariffs }\end{array}$ & $\begin{array}{l}\text { Overall extracted water at basin } \\
\text { level, constrained up to historical } \\
\text { records. Unconstrained use for } \\
\text { single farmer }\end{array}$ & Forbidden \\
\hline
\end{tabular}

Source: Own elaboration. 
As Table 3 shows, the current scenario (status-quo) depicts a situation in which the current users maintain their historical rights, while new authorization will not released. Farmer will not face any resource cost, except their private cost for water extraction from the ground. Finally, they are not allowed to sell water to other users.

In the case of the Intra-sector Market $(A)$, farmers are allowed to sell their use rights only to other farmers. Since we are referring to an agricultural district where intensive farming is limited by water availability, the restriction of market participation seems reasonable and necessary to create a climate of trust in markets among farmers, which is an indispensable condition to activate the market [24]. We assumed the absence of transaction costs, and free and complete information about water availability and price. According to the economic theory, the market would allow a more efficient allocation towards users capable of achieving higher groundwater productivity, with a consequent increase of agricultural wealth and farmers' revenue.

In order to consider the opportunity to allow non-farmers groundwater access, we considered the Regional Market $(B)$ scenario, where the public authority acts as a third party mediating agent, in order to prevent speculative actions and uneven access to the market. In this case, each participant may purchase use rights, regardless of the historical record. The public authority launches bidding calls at some determined level of pricing, to which farmers and non-farmers may participate. The level of the bid may also be conceived in terms of opportunity cost for water diversion for environmental uses, where the public authority acts to preserve the depletion of natural resources. Obviously, this scenario implies higher costs for farmers, but the removal of the historical constraints may allow the most efficient farmers to enlarge their irrigation operations, with a consequent increase in overall agricultural wealth and farmer's income as well.

\subsection{Economic Modeling}

A mathematical programming model has been applied in order to simulate farmers' decision making process under different groundwater use right settings. This kind of model is very frequent in the case of water allocation problems, due to the large heterogeneity of study areas, as well as the lack of data (either time series or cross sections) needed to adopt econometric models. In our case, we adopted a multi-agent territorial model, to simultaneously maximize the net return of the two types of farms, which are competing for the water resource available at basin level. Similar models have largely been reported in the scientific literature [25,26], and have also been applied to the Fortore river basin $[20,27,28]$. The most remarkable difference with previous models consists of the fact that instead of calculating the aggregated farms' revenue at basin level as the maximum sum of each farm's revenue multiplied by the number of operating farms (Max $N R=\eta \Sigma$ (Farm's revenue); in this case farm revenue is maximized for each farm type, and then we proceed with the weighted sum $(\Sigma \eta N R=($ Farms's revenue $))$. In our opinion, this approach seems more logically consistent with what actually happens in the real world, where farmers interact with each other at single level, rather than at aggregated level. Consequently, the regional model specification of a farm pursuing its revenue maximization (NR) under the current situation (status-quo), is formally described by the following:

$$
\Sigma \eta \operatorname{Max} N R=\left\{\Sigma x\left[q p-\Sigma(c v)-\Sigma \Sigma\left(a v^{w}\right)-m l s\right]-W c-F i x+S F P\right\}
$$


s.t.:

$\eta \Sigma(x t) \leq T$ : land use availability of farm type $j$, for each season $s$ is a constraint for the cultivation of the $\operatorname{crop} x$;

$\eta \Sigma(x \Sigma a) \leq W$ : irrigation water needs, depending on the specific water consumption $a\left(\mathrm{~m}^{3} / \mathrm{ha}\right)$ of crop $i$, is constrained by the water availability $W$, deriving from source $b$, and available for farm type $j$;

$\eta \Sigma(x l) \leq L$ : work load of type $c$ (hours) needed by the crop $i$ during the season $s$, is constrained by t the total labour availability $L$.

where:

$\eta$ : weight representing the number of farm type $j$;

$x$ : size of farmland (ha) devoted to the cultivation of the crop $i$, by farm type $j$;

$t$ : seasonal farmland use (ha per season $s$ ), needed by the crop $i$, during season $s$;

$T$ : farmland availability (ha), for season $s$ and farm type $j$;

$q, p:$ yields ( $\mathrm{t}$ ) and prices (EUR), of crop $i$;

$m l s$ : vector of production costs differences across farm types, due to economies of scale and different access to CAP subsidies, for crop $i$ and farm type $j$ (EUR/ha);

$c, v$ : technical coefficients of input $z(\mathrm{~kg} / \mathrm{ha})$, and its market price $(\mathrm{EUR} / \mathrm{kg})$;

$a v^{w}$ : specific water consumption for crop $i$, deriving for source $b$, and its tariff;

Fix : fixed costs faced by farm type $j$ (EUR/farm), including insurance, maintenance, overheads, and taxes;

$S F P$ : single farm payment, related to the EU CAP (EUR/farm);

$W C$ : irrigation fixed cost, referred to farm type $j$ (EUR).

In order to simulate the intra-sectoral market $(A)$ the model has been modified by introducing a variable representing the exchanged water from one farm type to the other ( $w$ and $w$ ), leading to the equation $(\eta \Sigma(x \Sigma a) \leq w-w+W)$, provided that $w$ and $w$ can be positive or negative, but $w-w=0$. This implies that farmers agree to a negotiated price $\left(v^{w^{\prime}}\right)$, which determines a cost to farms purchasing water $\left(v^{w^{\prime}} w\right)$ or a revenue to selling one $\left(+v^{w^{\prime}} w\right)$. The mathematical model will calculate the best water allocation, by allowing a transaction of water rights from the farm type characterized by lower water productivity, to those having higher values. The conditions for water rights exchange will disappear when the values for water productivity of both farms will equalize: $\lambda w=\lambda w==\lambda w$ for each $n$ belonging to $j$. In this case, $W$ may be conceived as the quota determined by the regulatory authority, in order to reduce the amount of water allocated to farmers, and therefore to save water for alternative uses.

With regard to the simulation of regional market (B), we eliminated the constraints representing the historical water uses $(\Sigma(x \Sigma a) \leq W)$ from the status-quo model, and we substituted it with a more relaxed constraint $(\eta \Sigma(x \Sigma a) \leq W)$. In addition, based on the assumption that the public authority acts as a third party mediating agent, it is supposed to start a bidding session, by defining a water tariff so that to clear the market or, alternatively, at a relatively higher tariff and that some water volumes are still available to be diverted to non-agricultural purposes. Therefore, the water tariff is conceived as a sort of resource cost corresponding to its opportunity cost $\left(v^{w}=v^{w}+\right.$ res_cost $)$. The equilibrium reached by the optimal solution will equalize the water productivity for every farm type $j$, with the 
resource cost $\left(\lambda_{j} w_{j}=r e s \_c o s t\right)$. Also in this case, the regulatory authority may reduce the quota allocated to irrigation $W$, in order to save water for environmental purposes, coherently with the WFD objectives.

Some more common model assumptions are described as follows. First of all, both types of farmers are assumed to pursue the net revenue, but differ in terms of the fixed endowment of production factors (land, labor, and capital). Secondly, we adopted a linear fixed coefficient production function, since the arid climate and the scarcity of rainfall during the cropping season force farmers to adopt the most common irrigation system on main profitable crops (tomato and horticultural crops). Indeed, localized drop irrigation is the largest irrigation system. In addition, technical coefficients, yields, prices, and other economic data are referred to years 2007-2008. The costs for production factors provided by the farming family are evaluated in terms of opportunity cost. The exchange of water use rights occur in absence of transaction costs, and a condition of complete information of exchanged volumes and prices. We forced this assumption due to the lack of estimations. Finally, we assumed that in order to calibrate the model, the cropping patterns of the status-quo scenario should correspond with the real data. Due to the lack of statistical data on groundwater extraction, we estimated a difference from the overall water needed by the irrigate crops and the water conveyed by the CBC.

\section{Results}

In this section we report the main findings derived from the comparison of the two alternative water use right settings (A) and (B), with the status-quo scenario. First of all, we analyze the performances of the two farm types, in order to evaluate their ability to adapt to the legislative change. Secondly, we run the model to obtain the aggregated results at basin level, in order to get a broad overview of the impact of the reform on the irrigated agriculture.

\subsection{Farm Level Analysis}

When we proceed with the farm level analysis, the farmer's objective to maximize net revenue is assumed. Additionally, amounts of water either from $\mathrm{CBC}$ and groundwater as well as their marginal productivity are assessed. In Table 4 the results in the case of the status-quo are shown.

Table 4. Overview of farm performances, under the status-quo scenario.

\begin{tabular}{|c|c|c|c|}
\hline & & T1 & T2 \\
\hline Water marginal productivity $\left(\mathrm{EUR} / \mathrm{m}^{3}\right)$ & & 0.1726 & 0.1484 \\
\hline Farm revenue (EUR/farm) & & 15,841 & 14,683 \\
\hline \multirow{2}{*}{ Water consumption $\left(\mathrm{m}^{3} /\right.$ year $)$} & $\mathrm{CBC}$ & 4,584 & 7,985 \\
\hline & Groundwater & 5,085 & 7,650 \\
\hline
\end{tabular}

Notes: T1 = Type 1 farms (intensive); T2 = Type 2 farms (less intensive), Source: own elaboration.

The absolute values of water marginal productivity in the status-quo scenario are different for each farm type and, in both cases they are higher than the private cost for groundwater extraction assumed to be equal to $0.09 \mathrm{EUR} / \mathrm{m}^{3}$. Under the no-constraints assumption, the groundwater demand for both farms will rise. Put in another way, it means that both firms would be better off pumping some 
additional groundwater. As a consequence, measures to limit groundwater extraction, in order to avoid its over-exploitation, are needed. Indeed, under the status-quo, the public authority have limited the groundwater abstraction by an allotment quota system, and ceased the release of new access licenses to the resource.

The absolute values of water marginal productivity are not equal. Differences may arise in the structural endowment factors, as well as in the different sets of possible crops, affecting the whole farm management. Under this situation, the opportunity for farms type T1 of purchasing additional water from farm type T2 clearly emerges. The exchange price will be defined through a negotiation process within the range $0.1484-0.1726 \mathrm{EUR} / \mathrm{m}^{3}$.

Afterward, the market scenario (A) which enables the exchange of the groundwater resource between the two farm types is implemented. Farmers also exchange groundwater use rights, provided they respect their initial allowance. In this way they can sell a maximum of groundwater volume, which reflects their historical allotments. As Table 5 shows, as far as farm type T1 purchases water, its marginal productivity decreases whereas its farm income increases. On the contrary, as long as farm type T2 sells water, its marginal productivity increases, as well as its farm income. Once the marginal productivity is the same, the exchanged volume amounts to $2,237 \mathrm{~m}^{3}$ and then the equilibrium is reached. In terms of farm revenue, both farmers gain from the market.

Table 5. Farms' performances under the intra-sector market scenario.

\begin{tabular}{ccccccc}
\hline Exchanged & T1 & T2 & T1 & T2 & T1 & T2 \\
\cline { 2 - 7 } water $\left(\mathrm{m}^{3}\right)$ & Marginal productivity $\left(\mathrm{EUR} / \mathrm{m}^{3}\right)$ & Farm revenue $(\mathrm{EUR} /$ farm) & Groundwater & use $\left(\mathrm{m}^{3}\right)$ \\
\hline 0 & 0.1726 & 0.1484 & 15,841 & 14,683 & 5,085 & 7,650 \\
1,442 & 0.1726 & 0.1484 & 15,857 & 14,703 & 6,527 & 6,208 \\
2,000 & 0.1726 & 0.1612 & 15,864 & 14,704 & 7,085 & 5,650 \\
2,237 & 0.1613 & 0.1613 & 15,866 & 14,705 & 7,322 & 5,413 \\
\hline
\end{tabular}

Notes: T1 = Type 1 farms (intensive); T2 = Type 2 farms (less intensive), Source: own elaboration.

Although the figures related to gains in farm revenue appear relatively small, it is important to remark that the amount of exchanged water is very significant, equivalent to 44 percent of the initial endowment for farm type T1, and 29 percent for farm type T2. It should be reminded that the buyer has to purchase groundwater at a price ranging from $0.1484-0.1726 \mathrm{EUR} / \mathrm{m}^{3}$, which already includes the extraction cost of $0.09 \mathrm{EUR} / \mathrm{m}^{3}$. In addition, the small magnitude of farm revenue may depend on the other structural constraints (e.g., family and hired labor availability), which determine additional financial costs reducing the water profitability at a lower level than expected. On the other hand, the seller receives money for water. However, he reduces irrigated crops on the farm which are most profitable with respect to the rain fed.

Now we turn to the case of the regional market scenario (B) where the removal of historical entitlements is applied. The access of groundwater resource under this hypothesis is liberalized and the authority creates a market devoted to water use rights auctions, which is opened to farmers. A maximum groundwater abstraction is only imposed at aggregated level given that each farmer can buy water depending on market price and marginal productivity. Nevertheless, since the access to 
groundwater use rights is open, it is expected that the farm type with the highest groundwater productivity will obtain the largest amount of water rights.

As Table 6 shows, it is worth noticing that farm type T1 finds it economically profitable to purchase higher water volumes with respect to the status-quo scenario. On the contrary, farm type T2 demands a lower volume of water. This different behavior has some relevant impacts on farm income. Indeed the farm type $\mathrm{T} 1$ gains from this scenario while the farm type $\mathrm{T} 2$ faces some loss. The difference of impacts becomes more evident as the public authority raises the resource tariff, from $0.03 \mathrm{EUR} / \mathrm{m}^{3}$, to $0.09 \mathrm{EUR} / \mathrm{m}^{3}$. This different effect can be explained in terms of the higher marginal productivity of the farm T1, as seen in the case of status-quo scenario. Although water marginal productivity decreases and the resource fee increases, water consumption remains unchanged whereas a decrease in farm revenue is found. This effect can be explained by the inelastic water demand faced by farms operating in arid and semi-arid environments [21,29,30].

Table 6. Farms' performances under the Regional market (B) scenario.

\begin{tabular}{|c|c|c|c|c|c|c|}
\hline \multirow[b]{2}{*}{$\begin{array}{l}\text { Resource fees } \\
\qquad\left(\mathrm{EUR} / \mathrm{m}^{3}\right)\end{array}$} & T1 & T2 & T1 & $\mathbf{T 2}$ & T1 & $\mathbf{T 2}$ \\
\hline & \multicolumn{2}{|c|}{$\begin{array}{c}\text { Marginal productivity } \\
\left(\mathrm{EUR} / \mathrm{m}^{3}\right)\end{array}$} & \multicolumn{2}{|c|}{ Farm revenue (EUR/farm) } & \multicolumn{2}{|c|}{ Groundwater use $\left(\mathrm{m}^{3}\right)$} \\
\hline 0 & 0.1623 & 0.1623 & 16,227 & 14,342 & 7,322 & 5,413 \\
\hline 0.03 & 0.1334 & 0.1334 & 15,991 & 14,167 & 7,322 & 5,413 \\
\hline 0.09 & 0.0613 & 0.0613 & 15,519 & 13,818 & 7,322 & 5,413 \\
\hline
\end{tabular}

Notes: T1 = Type 1 farms (intensive); T2 = Type 2 farms (less intensive), Source: own elaboration.

This aspect may hinder the process of farm adaptation to the liberalization of groundwater access and the application of a resource fee by the public authority. Consequently, some farmers may be worse-off and will probably be hostile to the reform.

\subsection{Basin Level Analysis}

In relation to the analysis at basin level, the comparison of the aggregated effect shown on Table 7 proves that by activating a market of water use rights some gains are achievable, in terms of value added. The market scenarios implemented here reach higher values for society welfare, but a reduction in overall water consumption does not occur. In that sense, in order to effectively save the groundwater resource, public authorities should apply some sort of constraint on water use (i.e., quota allowance) or in the case of the regional market, a resource tariff that overcomes water marginal productivity.

By analyzing the capacity of producing the wealth per unit of consumed water, the positive role of activating markets becomes more evident. Indeed, the ratio shows increasing values for both market settings with respect to the status-quo scenario. 
Table 7. Overall effects of legislative framework change at basin level.

\begin{tabular}{|c|c|c|c|c|c|}
\hline & \multirow{2}{*}{$\begin{array}{c}\text { V.A. } \\
\left(10^{6} \text { EUR }\right)\end{array}$} & \multirow{2}{*}{$\begin{array}{c}\text { Water use } \\
\left(10^{6} \mathrm{~m}^{3}\right)\end{array}$} & \multirow{2}{*}{$\begin{array}{c}\text { V.A./Water } \\
\left(\text { EUR/m } \mathbf{m}^{3}\right)\end{array}$} & \multicolumn{2}{|c|}{ Farm revenue change } \\
\hline & & & & $\mathbf{T 1}$ & $\mathbf{T 2}$ \\
\hline Status quo & 17.02 & 17.85 & 0.95 & - & - \\
\hline Intra-sector market* & 18.27 & 17.04 & 1.07 & $+0.10 \%$ & $+0.13 \%$ \\
\hline Regional market** & 18.54 & 17.16 & 1.08 & $+0.95 \%$ & $-3.51 \%$ \\
\hline
\end{tabular}

Source: own elaboration.

Notes: $(*)$ Amount of exchange water of $1,442 \mathrm{~m}^{3} / \mathrm{farm} .(* *)$ It is considered a resource fee of 0.03 $\mathrm{EUR} / \mathrm{m}^{3}$. The abbreviation for V.A. means "value added". T1 = Type 1 farms (intensive); T2 = Type 2 farms (less intensive).

Finally, the analysis of farms' revenue shows that the intra-sector market will be more acceptable, since there are positive effects in terms of revenue on both farm types. On the contrary, the regional market causes some uneven effects, as farm type T1 gains while farm type T2 loses.

\section{Concluding Remarks}

In recent decades, public concern about the creation of water markets to allow for the exchange of water use rights has also been raised in the interest of economists towards the potential gains either at individual or aggregated levels. Markets would likely enable the most efficient firms to make a better use of the resource, which could also attract private investors with the large investments needed to increase the supply of water resources.

However, theoretical frameworks considering the determinants for achieving a truly efficient use of the water resource remain insufficient due to some relevant issues, such as the role of transaction costs and information availability to market participants, which are still not well implemented in economic analyses. Furthermore, empirical studies are still scarce to grasp the real extent of possible gains which could be expected from the creation of an efficient market.

In addition, it should be emphasized that a monetary measure of the gains consequent to the legislative reform of property rights setting, is not suitable to evaluate the multifaceted functions exerted by the water resource in human society, to satisfy basic biological and health needs, and to guarantee ecological functions.

In this regard, in the recent conclusions at the 5th World Forum it is stated that water access is a basic need and that water policy should promote rules to guarantee a fair allocation among users, in order to also ensure access to weak social groups [31]. However, at the moment, due to lack of information on demand curves referring to different water uses in the area, modeling of the whole social gains derived from the diversion of water from irrigation purposes to other sectors (potable, industry, environment, and amenities) is not feasible.

According to the experience reported in this paper, we found some evidence that possible gains may be obtained by reforming the current legal framework regulating water use rights. However, the magnitude of the effects, as well as the fact that under certain conditions some user groups may lose, demonstrates that further analysis is needed and that these results may represent a support to policy makers and stakeholders involved in the reforming process. 


\section{References and Notes}

1. Sampat, P. Deep Trouble: The Hidden Threat of Groundwater Pollution; Worldwatch Paper No. 154; Worldwatch Institute: Washington, DC, USA, 2000.

2. European Environment Agency (EEA). Groundwater Quality and Quantity in Europe Data and Basic Information; Technical report No 22; EEA: Copenhagen, Denmark, 1999; Available online: http://www.eea.europa.eu/publications/TEC22/page001.html (accessed on 20 August 2011).

3. Gutiérrez, C.; Martin-Ortega, J.; Berbel, J. Situación y tendencias del uso agrícola del agua en la cuenca del Guadalquivir. Revista de Estudios Agrosociales y Pesqueros 2009, 220, 163-176.

4. Ingram, H. Water as a multi-dimensional value: Implications for participation and transparency. Int. Environ. Agreements 2006, 6, 429-433.

5. Civita, M.V.; Massarutto, A.; Seminara, G. Groundwater in the Southern Member States of the European Union: An Assessment of Current Knowledge and Future Prospects-Country Report for Italy; EASAC report; EASAC: Halle, Saale, Germany, 2008; Available online: http://www.easac.eu/fileadmin/PDF_s/reports_statements/Italy_Groundwater_country_report.pdf (accessed on 21 August 2011).

6. European Commission. Towards Sustainable Water Management in the European Union: First Stage in the Implementation of the Water Framework Directive 2000/60/EC; Commission Staff Working Document, SEC (2007), 362; European Commission: Brussels, Belgium, 2007; Available online: http://ec.europa.eu/environment/water/ waterframework/implrep2007/pdf/sec_ 2007_0362_en.pdf(accessed on 21 August 2011).

7. Bjornlund, H.; McKay, J. Aspects of water markets for developing countries experiences from Australia, Chile and the US. Int. Environ. Affair. 2002, 7, 767-793.

8. Horbulyk, T.M.; Lo, L.J. Welfare gains from potential water markets in Alberta, Canada. In Markets for Water-Potential and Preferences; Easter, K.W., Rosegrant, M.W., Dinar, A., Eds.; Kluwer Academic Publishers: Boston, MA, USA, 1998; pp. 241-258.

9. Garrido, A. Economic analysis of water markets in the Spanish agricultural sector: Can they provide substantial benefits. In Markets for Water-Potential and Preferences; Easter, K.W., Rosegrant, M.W., Dinar, A., Eds.; Kluwer Academic Publishers: Boston, MA, USA, 1998; pp. 223-240.

10. Olaizola, A. The water act and the transfer of rights of use: An analysis of terms of efficiency. In Proceedings of the 7th Conference of the International Water and Resource Economics Consortium and the Fourth Seminar on Environmental and Resource Economics, Girona, Spain, July 2001.

11. Armitage, R.M. An Economic Analysis of Surface Irrigation Water Rights Transfers in Selected Areas of South Africa; Water Research Commission: Pretoria, South Africa, 1999.

12. Bauer, C.J. Bringing water markets down to earth: The political economy of water rights in Chile, 1976-1995. World Dev. 1997, 25, 639-656.

13. Bjornlund, H. Farmer participation in markets for temporary and permanent water in southeastern Australia. Agr. Water Manag. 2003, 63, 57-76.

14. McCann, L.; Easter, K.W. A framework for estimating the transaction costs of alternative mechanisms for water exchange and allocation. Water Resour. Res. 2004, 40, 1-6. 
15. Pujol, J.; Raggi, M.; Viaggi, D. The potential impact of markets for irrigation water in Italy and Spain: A comparison of two study areas. Aus. J. Agr. Resour. Econ. 2006, 50, 361-380.

16. Bauer, C.J. Slippery property rights: Multiple water uses and the neoliberal model in Chile, 1981-1995. Nat. Resour. J. 1998, 38, 109-155.

17. Holden, P.; Thobani, M. Tradable Water Rights: A Property Rights Approach to Resolving Water Shortages and Promoting Investment, World Bank Policy Research Working Paper No. 1627; World Bank: Washington, DC, USA, 1996.

18. Bongaerts, J.C. European Water Law: Water policy and water resources management in France: The projet de loi sur l'eau. Eur. Environ. Law Rev. 2002, August/September, 239-244.

19. D'Arcangelo, G.; Nardella, L.; Rodio, M.E. Analysis of water requirement and consumptions in a public district of recent irrigation: The case of sub districts 5b, 12 and 13. Bonifica 2005, 4, 34-42.

20. Giannoccaro, G.; Prosperi, M.; Valente, N.; Zanni, G. Valutazione degli Impatti della Politica di Tariffazione delle Acque Irrigue sull'Agricoltura della Capitanata. In Acqua e Agricoltura in Italia: Valutazioni di Scenari e Strumenti di Supporto alle Decisioni; Gallerani, V., La Via, G., Zanni, G., Eds.; Franco Angeli: Milano, Italy, 2009; pp. 121-149.

21. Nardone, G.; Prosperi, M.; Viscecchia, R.; Zanni, G. Valutazione economica della risorsa idrica nell'agricoltura della Capitanata. In Risorse Idriche in Provincia di Foggia; CCIAA: Foggia, Italy, 2007; pp. 79-111.

22. Rinaldi, M.; Soldo, P.; Tucci, G.; Rana, G. Relazioni tra variazioni climatiche, risorse idriche e produzioni in Capitanata nell'ultimo decennio. In Proceedings of the AIAM Congress 'L'Agrometeorologia nel Mediterraneo, Acireale, Italy, 6-7 June 2002; Available online: http://www.agrometeorologia.it/documenti/aiam2002/132-143Rinaldi.pdf (accessed on 20 August 2011).

23. PTA (Piano di Tutela Acque) Regione Puglia. Bollettino Ufficiale della Regione Puglia 2009, 130 suppl, 4-8.

24. Hong, Y.; Zhang, X.; Zehnder, A.J.B. Water scarcity, pricing mechanism and institutional reform in northern China irrigated agriculture. Agr. Water Manag. 2003, 61, 143-161.

25. Tisdell, J. G. The environmental impact of water markets: An Australian case-study. J. Environ. Manag. 2001, 62, 113-120.

26. Berbel, J.; Gutierrez, C. Sustainability of European Agriculture under Water Framework Directive and Agenda 2000; European Commission: Brussels, Belgium, 2005; p. 167.

27. Chinnici, G.; Gallerani, V.; Giannoccaro, G.; Prosperi, M.; Raggi, M. Viaggi, D.; Zanni, G. Regolazione dell'uso dell'acqua a scopo irriguo: Opzioni ed effetti negli scenari post riforma 2003. In Proceedings of the XLI Convegno SIDEA 'Agricoltura e mercati in transizione', Assisi, Italy, 7-9 September 2006.

28. Giannoccaro, G.; Prosperi, M.; Zanni, G. L'efficienza delle politiche idriche in relazione alle scelte di schema e di livello tariffario per lo scenario 2015. In Proceedings of the XLV Convegno SIDEA 'Politiche per $i$ Sistemi Agricoli di Fronte ai Cambiamenti: Obiettivi, Strumenti, Istituzioni', Portici, Italy, 25-27 September 2008; ISBN 9788849519242.

29. Varela-Ortega, C.; Sumpsi, J.M.; Garrido, A.; Blanco, M.; Iglesias, E. Water pricing policies, public decision making and farmers' response: Implications for water policy. Agr. Econ. 1998, 19, 193-202. 
30. Berbel, J.; Gomez-Limon, J. The impact of water-pricing policy in Spain: An analysis of three irrigated areas. Agr. Water Manag. 2000, 43, 219-238.

31. World Water Forum. Bridging Divides for Water; Thematic Documents: Istanbul, Turkey, 2009; Available online: http://content.worldwaterforum5.org/files/ThematicDocuments (accessed on 30 August 2009).

(C) 2011 by the authors; licensee MDPI, Basel, Switzerland. This article is an open access article distributed under the terms and conditions of the Creative Commons Attribution license (http://creativecommons.org/licenses/by/3.0/). 